\title{
ASYMBIOTIC GERMINATION, SEEDLING DEVELOPMENT AND PLANTLET PROPAGATION OF ENCYCLIA AFF. ONCIDIOIDES - AN ENDANGERED ORCHID
}

\author{
JOANNA ZNANIECKA ${ }^{1}$, ALEKSANDRA KRÓLICKA ${ }^{1}$, \\ MATYLDA SIDWA-GORYCKA ${ }^{1}$, JAN J. RYBCZYŃSKI ${ }^{2}$, \\ DARIUSZ L. SZLACHETKO ${ }^{3}$, EWA ŁOJKOWSKA ${ }^{1}$ \\ ${ }^{1}$ Department of Plant Protection and Biotechnology \\ Intercollegiate Faculty of Biotechnology \\ University of Gdańsk and Medical University of Gdańsk \\ Kładki 24, 80-822 Gdańsk, Poland \\ e-mail: lojkowsk@biotech.univ.gda.pl \\ ${ }^{2}$ Botanical Garden - Centre of Biological Diversity Conservation \\ Polish Academy of Sciences \\ Prawdziwka 2, 02-973 Warszawa, Poland \\ ${ }^{3}$ Department of Plant Taxonomy and Nature Conservation \\ University of Gdańsk \\ Al. Legionów 9, 80-441 Gdańsk, Poland \\ (Received: February 11, 2005. Accepted: May 18, 2005)
}

\begin{abstract}
In order to estimate the best germination conditions of Encyclia aff. oncidioides seeds, five different media (Fast, Knudson C modified by Vajrabhaya, Murashige and Skoog, PB2 and modified Vacin and Went) with different concentrations of plant growth regulators such as benzyladenine (BA), naphthaleneacetic acid (NAA) and gibberellic acid $\left(\mathrm{GA}_{3}\right)$ were tested. No beneficial effect was observed when BA and NAA were applied to the germination medium and $\mathrm{GA}_{3}$ inhibited germination. The effect of light, activated charcoal, coconut water and casein hydrolysate on seed germination was also studied. The growth rate of seedlings on three different media supplemented with activated charcoal and plant growth regulators was checked. The applied plant growth regulators had no beneficial effect on the further growth of seedlings. Fast and $\mathrm{PB}_{2}$ media with $0.2 \%$ activated charcoal proved to be the best for $E$. aff. oncidioides seed germination, seedling development and plantlet propagation.
\end{abstract}

KEY WORDS: asymbiotic germination, endangered plants, in vitro propagation, orchids.

\section{INTRODUCTION}

The neotropical genus Encyclia was described by Hooker in 1828 (Index Kewensis 1997). It belongs to Epidendreae Humb., Bonpl. \& Kunth, a tribe very difficult and problematic from the taxonomical viewpoint. For decades Encyclia was confused and combined with the rather distantly related genus Epidendrum L. This confusion resulted in the enlargement of the list of species described either as Encyclia or Epidendrum. The International Plant Names Index (http://www.ipni.org) listed as many as 865 names under Encyclia. A partial solution of the taxonomic problems concerning Encyclia/Epidendrum-complex was proposed by Higgins (1997) who reestablished an old genus Prosthechea Knowl. and Westc., 1838. The genera Encyc- lia and Prosthechea differ clearly from one another because of their vegetative characters. Encyclia embraces epiphytic or epilithic species adapted to relatively dry conditions (savannah, rock-savannah) and characterized by thick leaves and inflorescence with no spatha. Their flowers are usually resupinate. Prosthechea contains mostly epiphytic species growing in various forms of forests (often rain-forests or cloud-forests). These orchids have thin leaves, the basal part of inflorescence covered by prominent spatha and often non-resupinate flowers. Such defined genera $E n$ cyclia and Prosthechea are represented by 100 and 90 species, respectively.

Orchids belong to endangered species and are threatened with extinction all over the world. There are several factors that influence their existence: deforestation and fragmenta- 
tion of habitat - especially in tropical regions, excessive exploitation of soil, increased use of fertilizers and over collection. The seeds of most orchid species are minute (they can range in weight from 0.4 to $14 \mu \mathrm{g}$ ) and posses no endosperm or other external nutrient tissue (Arditti 1992). In natural conditions, in order to germinate, orchids require the presence of symbiotic fungi (Mitchell 1989). Additionally, their very long life cycle and low reproduction rate makes it very difficult for wild orchids to re-establish their position in natural habitats. Creating national parks and nature reserves plays a very important role in conservation, but it may not be enough (Szlachetko 1995). Despite their legal protection, orchid population is steadily decreasing. In vitro propagation techniques have proved to be powerful tools in the conservation of endangered orchids (Butcher and Marlow 1989; Ramsay and Stewart 1998; Sheelavantmath et al. 2000; Lo et al. 2004). Germination of the most of orchid species relies on symbiotic fungus, however most of them are able to germinate asymbiotically when special medium and culture conditions are provided.

The presented investigation was carried out in order to: develop a reliable protocol for asymbiotic germination of seeds and in vitro propagation of $E$. aff. oncidioides plantlets - and thus contribute to the preservation of this endangered species.

\section{MATERIAL AND METHODS}

\section{Plant material}

Encyclia aff. oncidioides seeds were taken from a fresh capsule produced by natural pollination. Fresh capsule was collected by Prof. D.L. Szlachetko in the wild regions of French Guyana. An unripe, intact capsule was surface-disinfected in $5 \%(\mathrm{v} / \mathrm{w})$ calcium hypochlorite $(\mathrm{POCH}, \mathrm{Po}-$ land) for $15 \mathrm{~min}$, afterwards the capsule was dipped in $70 \%$ ethanol and passed directly through a flame. The capsule was then dissected longitudinally with a sharp sterilized surgical blade in the laminar airflow cabinet and the seeds were scooped out and sown on 5 different $0.7 \%$ agar solidified media. Approximately 600 seeds were sown in every culture vessel.

\section{Germination conditions}

Germination of $E$. aff. oncidioides seeds was performed on five media: Fast (1981), Knudson C (KC) modified by Vajrabhaya (1978), MS with ten times diluted macroelements (Murashige and Skoog 1962), Tsuchiya medium modified by Kukułczanka and Sarosiek (1971) supplemented with Heller's microelements $\left(\mathrm{PB}_{2}\right)$ (Kukułczanka and Paluch 1971) and Vacin and Went (VW) medium (Vacin and Went 1949) modified by addition of ferrous sulphate instead of ferric ethylenediamine tetraacetate. The media were supplemented with casein hydrolysate $(0.01 \% \mathrm{v} / \mathrm{w})$, coconut water $(5 \%)$, activated charcoal - Sigma $(0.2 \%$ $\mathrm{v} / \mathrm{w}), \mathrm{GA}_{3}$ at concentrations from 1.0 to $10 \mu \mathrm{M}$, BA at concentrations from 2.0 to $10 \mu \mathrm{M}$, and NAA at concentrations from 0.2 to $1.0 \mu \mathrm{M}$ in various combinations. The $\mathrm{pH}$ of media was adjusted to 5.4 prior to autoclaving. Filter sterilized plant growth regulators were added after autoclaving.

Germination was performed either in continuous darkness at $23^{\circ} \mathrm{C}$ or under a $16 / 8$ (day/night) photoperiod and illumination of $30-35 \mu \mathrm{mol} \cdot \mathrm{m}^{-2} \cdot \mathrm{s}^{-1}$.
Germination was considered to have occurred when imbibed embryos released from their seed coats were observed. Stages of germination and seedling growth were recorded using a scale of 0 to $6: 0$ - seed, 1 - imbibed seed, 2 - enlarged embryo released from the seed coat, 3 - protocorm, 4 - protocorm highly enlarged with a shoot initial, 5 - protocorm with a shoot, 6 - protocorm with the second leaf.

\section{Culture conditions}

Protocorm, seedling and plantlet cultures were maintained on Fast, $\mathrm{MS}, \mathrm{PB}_{2}$ or VW media at $23^{\circ} \mathrm{C}$ under a $16 / 8$ (day/ night) photoperiod and illumination of $30-35 \mu \mathrm{mol} \cdot \mathrm{m}^{-2} \cdot \mathrm{s}^{-1}$. Growth rate of cultures was evaluated 4, 9 and 24 weeks after sowing.

\section{Shoot micropropagation}

Two year old plants were used for micropropagation. As the source of explants, plants of even growth rate $(5-7 \mathrm{~cm})$ were chosen. The top parts of shoots, measuring about 5 $\mathrm{mm}$ were excised and placed on two liquid media: $\mathrm{PB}_{2}$ and VW supplemented with $5 \%$ coconut water. The multiplication rate, expressed as a number of protocorm like bodies (PLB) regenerated from one explant within nine months of culture were calculated for each treatment.

\section{RESULTS AND DISCUSSION}

In vitro germination and plantlet development is considered to be an appropriate method for propagation and conservation of orchids (Van Waes and Debergh 1986). The asymbiotic germination of seeds has been used for production of many orchid species (Arditti 1992). Seeds in immature capsules are easier for surface sterilisation. According to the data of Arditti (1992) seeds from immature or mature capsules, depending on the orchid species, are a valuable source of in vitro plants.

A marked variation was observed in germination of Encyclia seeds cultured on different media (Fig. 1). The highest percentage of germination (about 95\%) was observed on both Fast and $\mathrm{PB}_{2}$ media devoid of plant growth regulators (Table 1). This can be caused by the presence of sufficient endogenous plant growth hormones required for the germination. The germinating embryos on these media were intensely green when grown on light. Embryos grown on Fast medium supplemented with activated charcoal, observed under the microscope after 4 weeks of culture, were round and already released from the testa (Fig. 1A). Figures 1A-D present various responses of seed germination intensity on different media. They were taken simultaneously and enabled evaluation of the efficiency of proliferation. Light had no influence on initiation of the germination process and the addition of coconut water and casein hydrolysate had no positive effect either on initiation of the germination process or on the further growth of the seedlings. The presence of $0.537 \mu \mathrm{M}$ NAA significantly slowed down germination (Fig. 1B and $\mathrm{C}$ ), moreover, supplementation of media with $10 \mu \mathrm{M} \mathrm{GA}_{3}$ inhibited germination (Fig. 1D). Although auxins and cytokinins are extensively used in orchid tissue culture media (Arditti and Ernst 1993), their influence on germination may vary among orchid genera. NAA has been reported beneficial for Vanda germination 


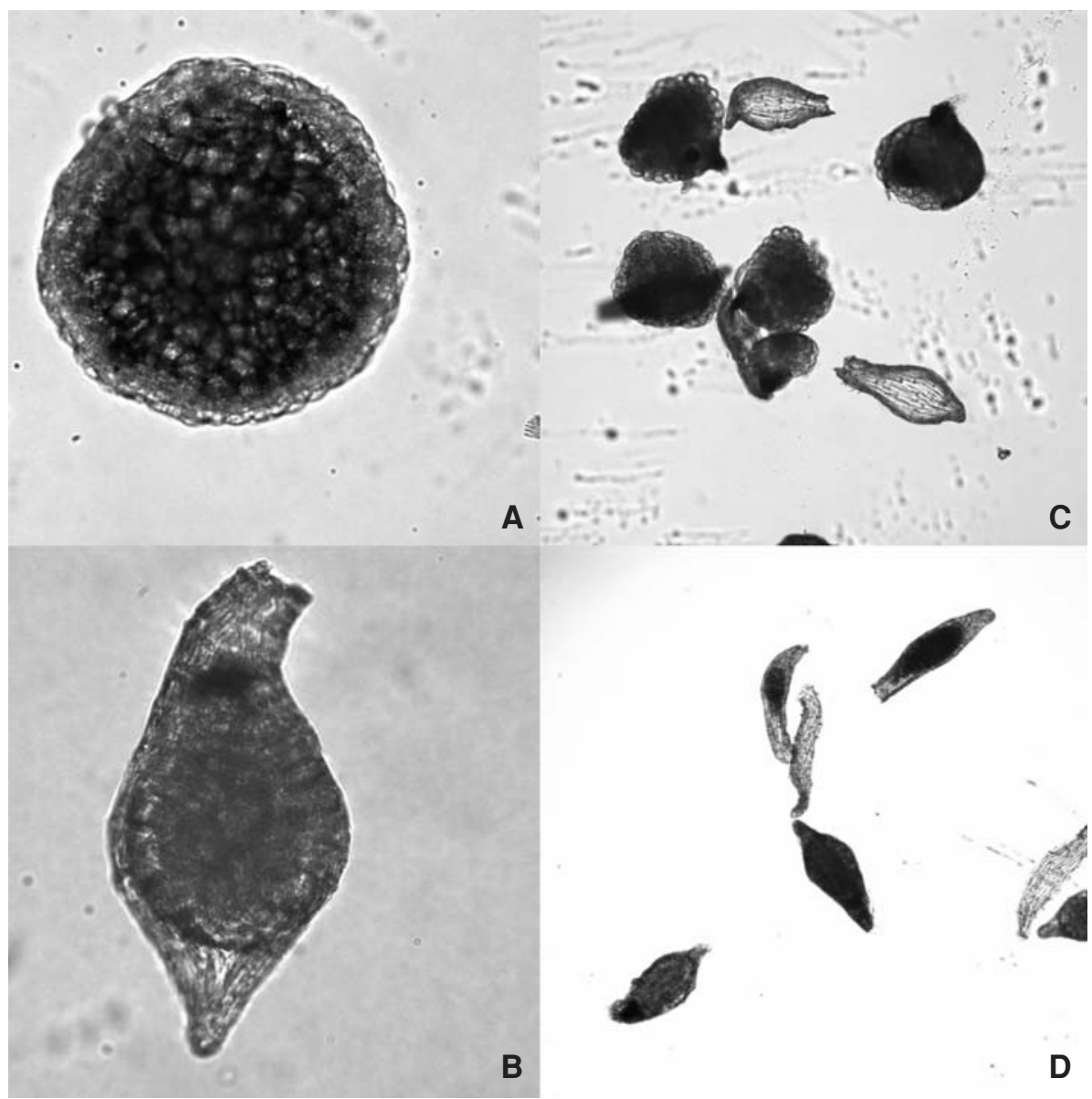

Fig. 1. A - Encyclia aff. oncidioides enlarged embryo released from the seed coat on medium Fast (Fast 1981) supplemented with activated charcoal after 4 weeks of culture $(\times 20)$; B - Encyclia aff. oncidioides imbibed seed with slightly enlarged embryo on medium 0.1 MS (Murashige and Skoog 1962) supplemented with NAA after 4 weeks of culture $(\times 40)$; C - Encyclia aff. oncidioides imbibed seeds with enlarged embryos on medium 0.1 MS (Murashige and Skoog 1962) supplemented with NAA after 4 weeks of culture $(\times 10)$; D - Encyclia aff. oncidioides seeds on medium 0.1 MS (Murashige and Skoog 1962) supplemented with $\mathrm{GA}_{3}$ after 4 weeks of culture $(\times 10)$.

TABLE 1. Effect of culture medium on asymbiotic germination of Encyclia aff. oncidioides seeds.

\begin{tabular}{|c|c|c|c|}
\hline Medium & Activated charcoal & Evaluation of germination stage and the colour of embryo & Percentage of germinated seeds \\
\hline & + & green and enlarged embryos released from the seed coats -2 & 95 \\
\hline Fast & - & imbibed seeds with green embryos -1 & 40 \\
\hline \multirow[t]{2}{*}{ Knudson C } & + & mostly no germination was observed with few imbibed seeds -0 & 15 \\
\hline & - & no germination was observed -0 & 0 \\
\hline \multirow[t]{2}{*}{$0.1 \mathrm{MS}$} & + & imbibed seeds -1 & 55 \\
\hline & - & mostly no germination was observed with few imbibed seeds -0 & 25 \\
\hline \multirow[t]{2}{*}{$\mathrm{PB}_{2}$} & + & green and enlarged embryos released from the seed coats -2 & 95 \\
\hline & - & green and enlarged embryos released from the seed coats -2 & 95 \\
\hline \multirow[t]{2}{*}{ VW } & + & imbibed seeds with green embryos -1 & 75 \\
\hline & - & imbibed seeds with green embryos -1 & 75 \\
\hline
\end{tabular}

Evaluation of germination stage was performed 4 weeks after sowing

(Mathews and Rao 1980). Morel (1960) stated that Cattleya growth is improved when casein hydrolysate is added to MS medium. Our findings have not confirmed those presented by Morel, however it is difficult to compare these results due to the fact that modification of MS medium used in our study differed from the one recommended by Morel (1960).

The first passage of seedlings was performed after 9 weeks of culture. The seedlings were transferred to fresh media in various stages of development: protocorms, protocorms with shoot initials and protocorms with the first leaf (Fig. 2). In order to estimate the best conditions for the further growth, seedlings were cultured on three media: Fast,
MS (with ten times diluted macroelements), and PB2 (Table 2 ). These media were supplemented with $0.01 \%$ casein hydrolysate, $5 \%$ coconut water, $0.2 \%$ activated charcoal and/or $0.537 \mu \mathrm{M}$ NAA.

No positive effect on the seedling growth of any applied component (data not shown), apart from activated charcoal, was noted (Table 2). The best growth was observed when seedlings were transferred either from medium Fast supplemented with activated charcoal or $\mathrm{PB}_{2}$ without activated charcoal to Fast and $\mathrm{PB}_{2}$, both supplemented with activated charcoal (Fig. 3) or to $\mathrm{PB}_{2}$ without activated charcoal (Table 2). When seeds were germinating on an initial, unsuitable medium (MS with ten times diluted macroelements), 


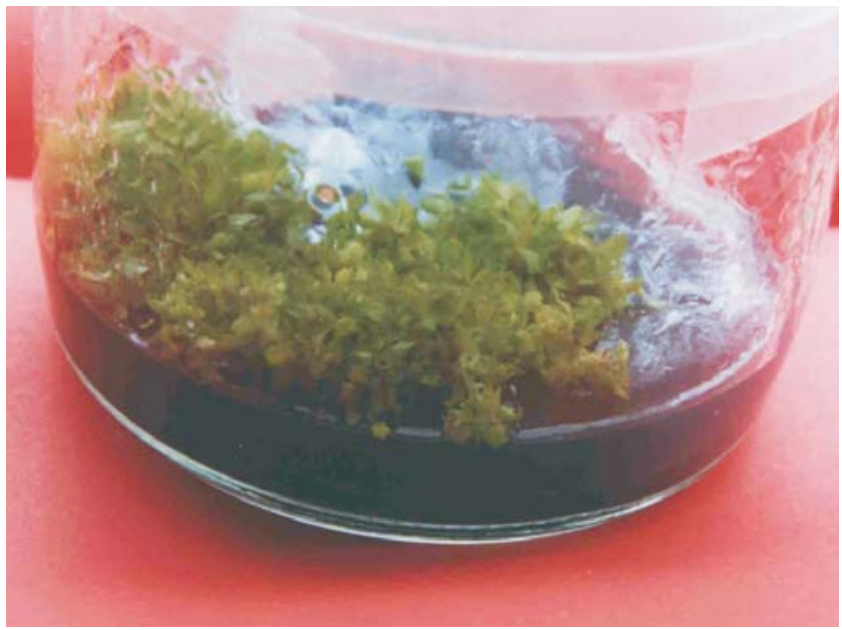

Fig. 2. Encyclia aff. oncidioides seedlings on medium Fast (Fast 1981) supplemented with activated charcoal after 18 weeks of culture.

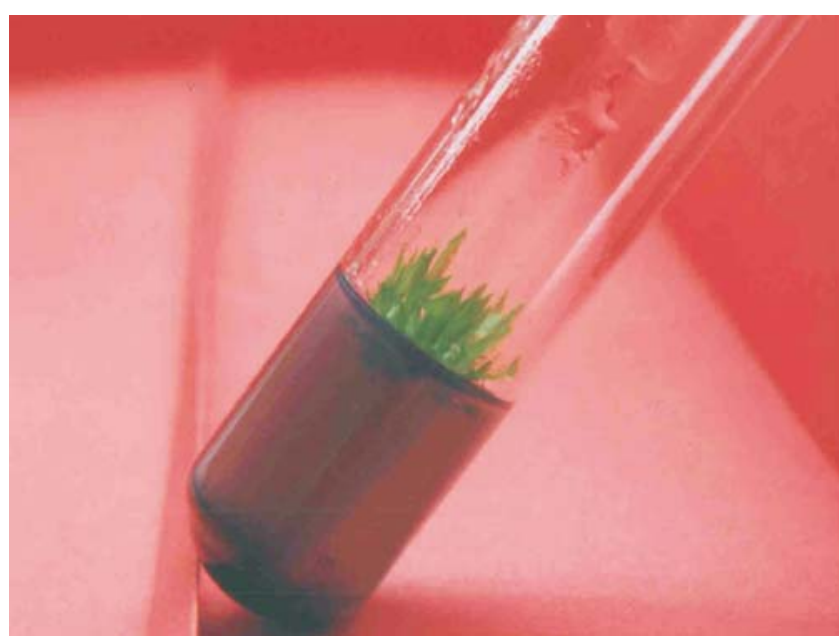

Fig. 3. Encyclia aff. oncidioides seedlings on medium Fast (Fast 1981) supplemented with activated charcoal after 24 weeks of culture.

TABLE 2. Effect of medium and activated charcoal on the growth of Encyclia aff. oncidioides seedlings.

\begin{tabular}{|c|c|c|c|c|}
\hline \multirow{2}{*}{$\begin{array}{l}\text { Media used } \\
\text { for seed germination }\end{array}$} & \multicolumn{4}{|c|}{ Media tested for the growth of the seedlings } \\
\hline & Fast $+\mathrm{AC}$ & $0.1 \mathrm{MS}+\mathrm{AC}$ & $\mathrm{PB}_{2}$ & $\mathrm{~PB}_{2}+\mathrm{AC}$ \\
\hline Fast $+\mathrm{AC}$ & $\begin{array}{l}\text { protocorm } \\
\text { with the second leaf }-6\end{array}$ & $\begin{array}{l}\text { highly enlarged protocorm } \\
\text { with shoot initial - } 4\end{array}$ & $\begin{array}{l}\text { highly enlarged protocorm } \\
\text { with shoot initial - } 4\end{array}$ & protocorm with shoot -5 \\
\hline $0.1 \mathrm{MS}+\mathrm{AC}$ & $\begin{array}{l}\text { highly enlarged protocorm } \\
\text { with shoot initial - } 4\end{array}$ & protocorm -3 & $\begin{array}{l}\text { protocorm } \\
\text { with the second leaf }-6\end{array}$ & $\begin{array}{l}\text { protocorm } \\
\text { with the second leaf }-6\end{array}$ \\
\hline $\mathrm{PB}_{2}$ & $\begin{array}{l}\text { protocorm } \\
\text { with the second leaf }-6\end{array}$ & protocorm with shoot -5 & $\begin{array}{l}\text { protocorm } \\
\text { with the second leaf }-6\end{array}$ & $\begin{array}{l}\text { protocorm } \\
\text { with the second leaf }-6\end{array}$ \\
\hline VW & $\begin{array}{l}\text { highly enlarged protocorm } \\
\text { with shoot initial - } 4\end{array}$ & $\begin{array}{l}\text { highly enlarged protocorm } \\
\text { with shoot initial - } 4\end{array}$ & $\begin{array}{l}\text { highly enlarged protocorm } \\
\text { with shoot initial - } 4\end{array}$ & $\begin{array}{l}\text { highly enlarged protocorm } \\
\text { with shoot initial - } 4\end{array}$ \\
\hline
\end{tabular}

Evaluation was performed after 24 weeks after sowing;

$\mathrm{AC}$ - activated charcoal

and then transferred to a medium supporting growth (Fast or $\mathrm{PB}_{2}$ ), their performance improved significantly (Table 2). When the pattern was just the opposite - seedlings transferred from initially efficient medium to the one with worse properties - at the beginning their performance remained satisfactory but later on their development was very slow (Table 2).

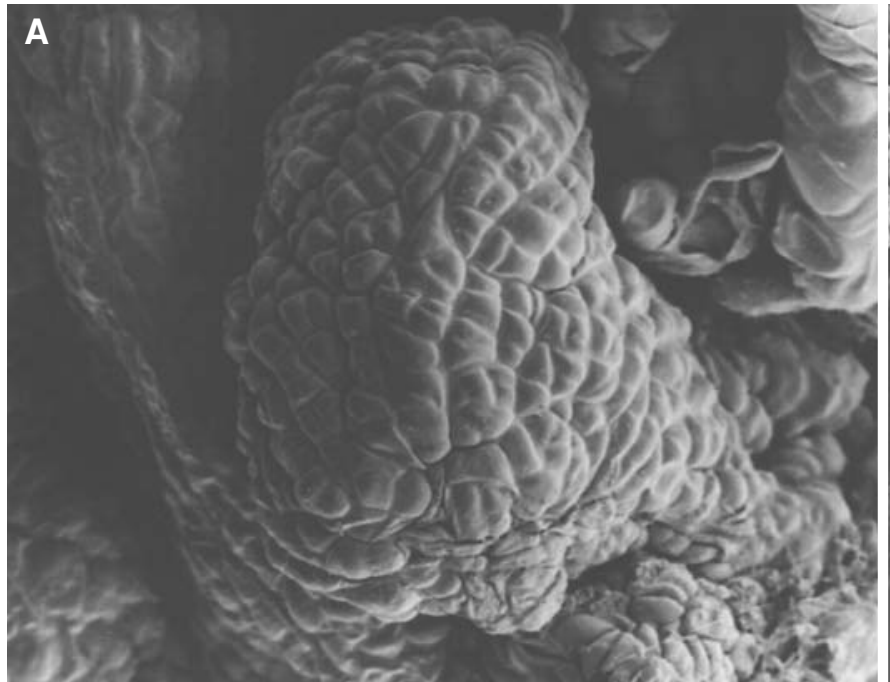

The addition of activated charcoal to the medium promoted the growth of seedlings (Table 2). During germination and the subsequent growth of the seedlings, darkening of the media was observed which was probably caused by accumulation of phenolic compounds and their oxidation products. The possible mechanism by which activated charcoal influences the growth of seedlings can be explai-

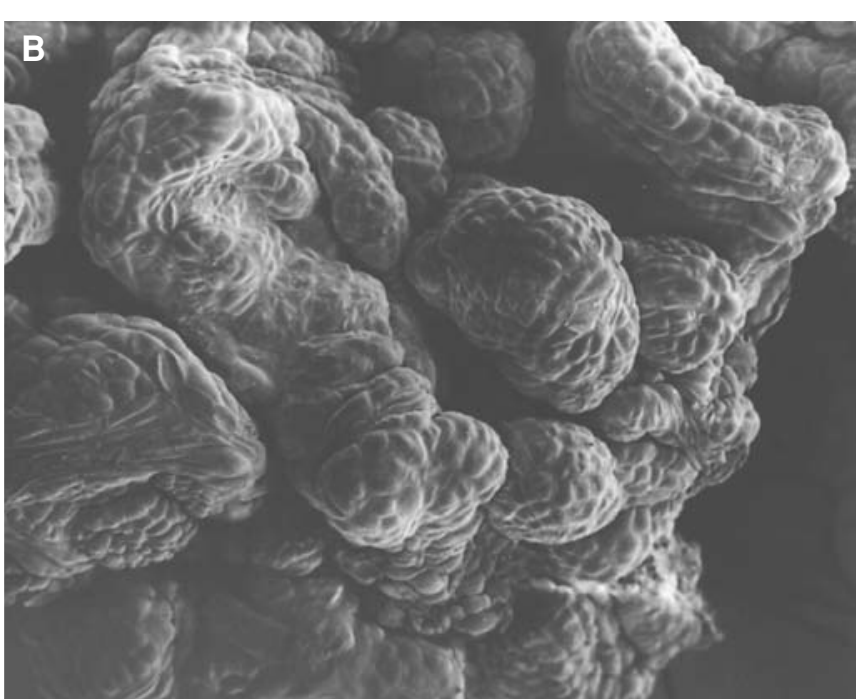

Fig. 4. Scanning electron micrographs showing early stages of cell proliferation and formation of Encyclia aff. oncidioides protocorm like bodies (PLB) $(\mathrm{A} \times 200, \mathrm{~B} \times 100)$. 


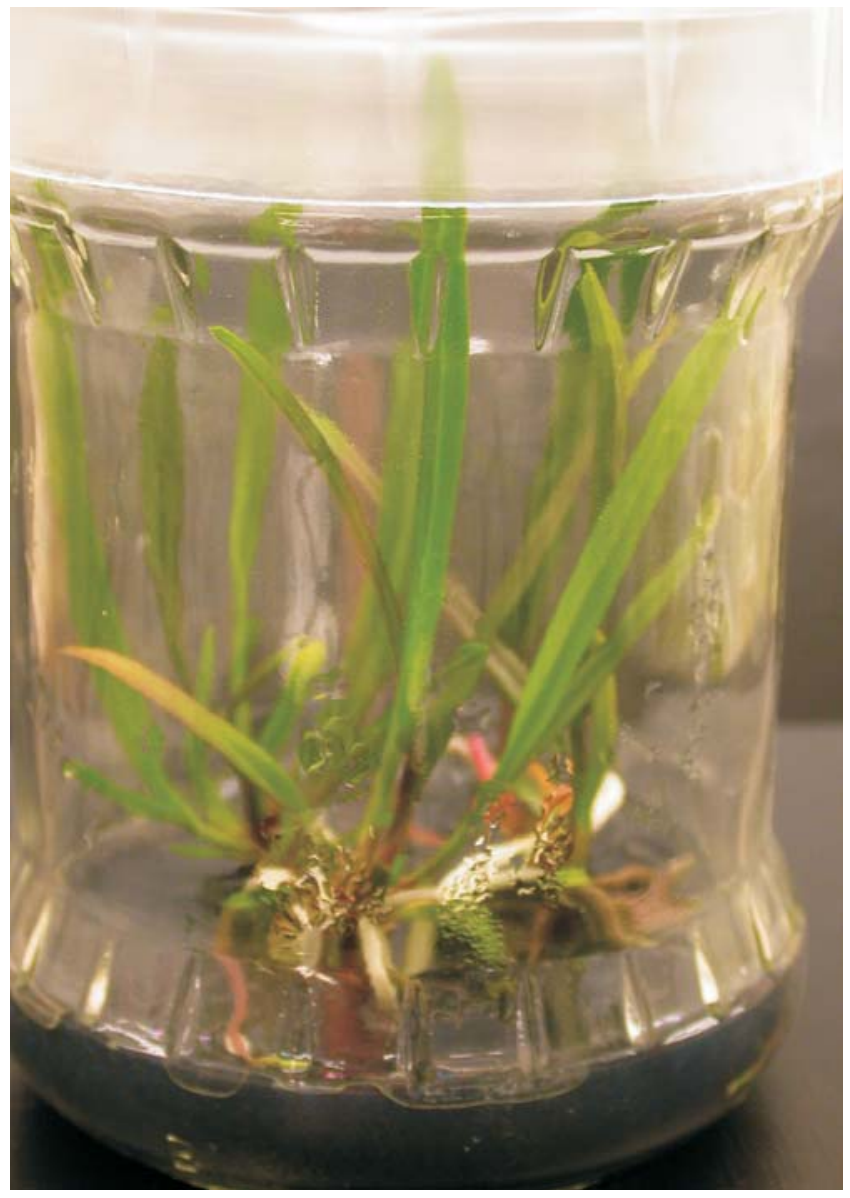

Fig. 5. Encyclia aff. oncidioides plants on medium Fast (Fast 1981) supplemented with activated charcoal after 2 years of culture. ned by the adsorption of the phenolic compounds released into the medium by the explant or by the germinating seed (Yam et al. 1990). Darkening of the media caused by an accumulation of phenolics has been reported in the culture of orchids (Ernst 1974; Ichihashi and Kako 1977). Phenolics and poliphenoloxidates - phenol oxidation products are phytotoxic. Our findings concerning the usefulness of activated charcoal are in agreement with the information reported by Yam et al. (1990) and Werkmeister (1970).

Preliminary experiments with shoot micropropagation indicate that media $\mathrm{PB}_{2}$ and modified $\mathrm{VW}$ are suitable for micropropagation of E. aff. oncidioides (Fig. 4A, B). The multiplication rate (number of protocorm obtained from explant) on medium $\mathrm{PB}_{2}$ was 12 and on medium Vacin and Went (VW) 10.

Fast and $\mathrm{PB}_{2}$ media supplemented with activated charcoal proved to be very effective for germination as well as for subsequent growth of seedlings (Fig. 2 and 3). Well-developed plants (Fig. 5) were transferred to community pots and then to a greenhouse where the plants were acclimatised and produced flowers within four years of vegetation (Fig. 6A, B). The efficiency of germination, seedling formation and in vitro micropropagation indicate that in vitro culture is a feasible method for rapid propagation of $E$. aff. oncidioides and can be used for its conservation.

\section{ACKNOWLEDGEMENTS}

This work was supported by the State Committee for Scientific Research (KBN) grant: 3 P04C 09925.

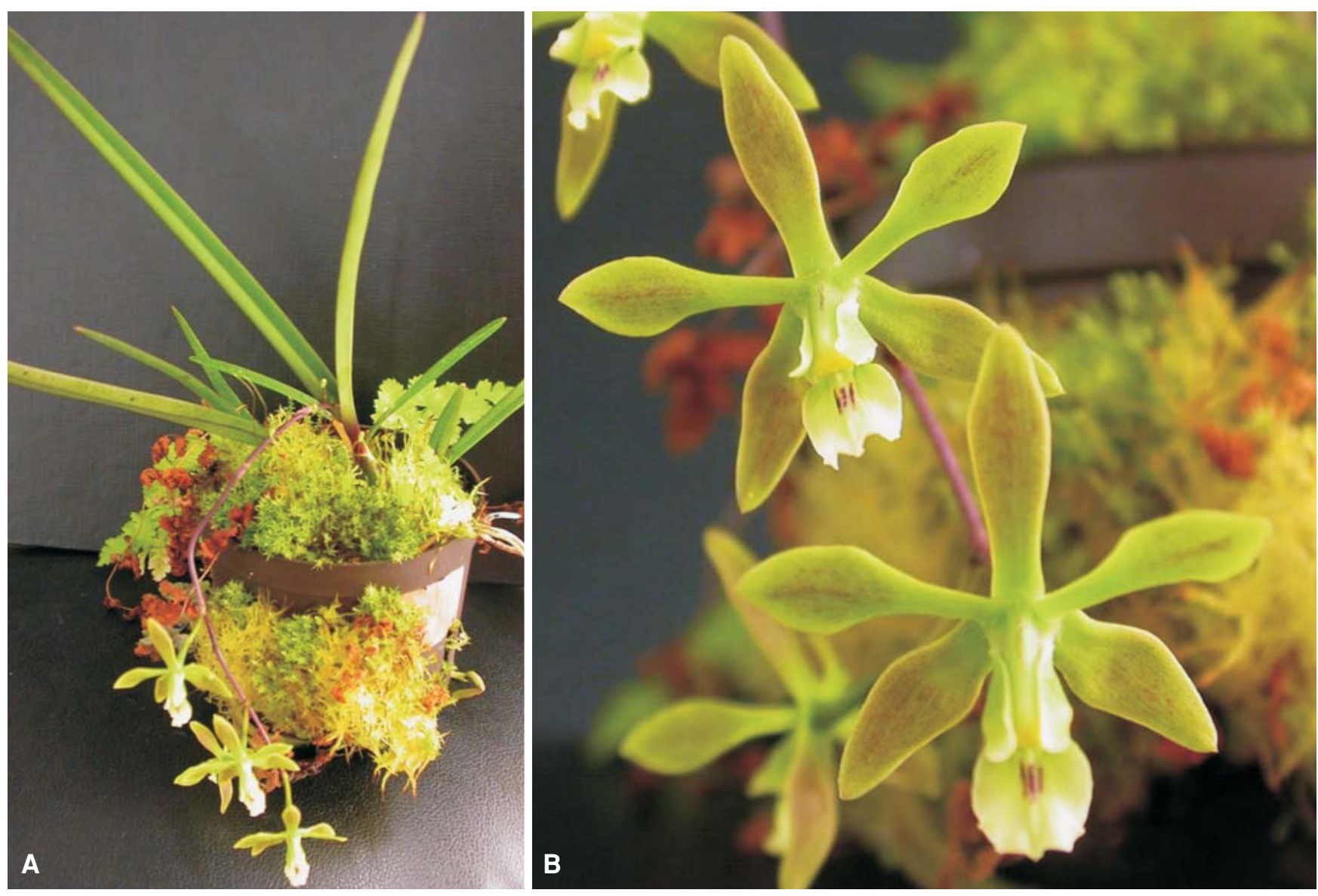

Fig. 6. Encyclia aff. oncidioides blooming plants after 4 years of vegetation. 


\section{LITERATURE CITED}

ARDITTI J. 1992. Fundamentals of Orchid Biology. John Wiley and Sons, INC. New York. pp. 122.

ARDITTI J., ERNST R. 1993. Micropropagation of Orchids. John Wiley and Sons, INC. New York. pp. 13.

BUTCHER D., MARLOW S.A. 1989. Asymbiotic germination of epiphytic and terrestrial orchids. In Pritchard H.W. (ed.) Modern methods in orchid conservation: the role of physiology, ecology and management. Cambridge Univ. Press, Cambridge. pp. 31-38.

ERNST R. 1974. The use of activated charcoal in asymbiotic seedling culture of Paphiopedilum. Amer. Orchid Soc. Bull. 43: 35-38.

FAST G. 1981. Orchideen Kultur. Stuttgart pp. 220.

HIGGINS W.E. 1997. A reconsideration of the genus Prosthechea (Orchidaceae) Phytologia 82 (5): 370-38.

ICHIHASHI S., KAKO S. 1977. Studies on clonal propagation of Cattleya through tissue culture method II. Browning of Cattleya. J. Jpn. Soc. Hort. Sci. 46: 325-330.

INDEX KEWENSIS 2.0. 1997. CD. Oxford University Press.

KUKUŁCZANKA K., PALUCH B. 1971. Zastosowanie peptonu Peptobak-Bacutil w hodowli merystematycznej tkanki Cymbidium Sw. Acta Agrobotanica XXIV, 1: 52-62. (in Polish)

KUKUŁCZANKA K., SAROSIEK J. 1971. Merystematyczne kultury storczyków. Wiadomości Botaniczne XV, 1: 29-40. (in Polish)

LO S.-F., NALAWADE S.M., KUO C.-L., CHEN C.-L. TSAY H.-S. 2004. Asymbiotic germination of immature seeds, plantlet development and ex vitro establishment of plants of Dendrobium tosaense Makino - a medicinally important orchid. In Vitro Cell Dev. Biol. Plant 40: 528-535.

MATHEWS V.H., RAO P.S. 1980. In vitro multiplication of Vanda hybrids through tissue culture technique. Plant Science Letters 17: 383-389.
MITCHELL R.B. 1989. Growing hardy orchids from seed at Kew. The Plantsman 2: 152-169.

MOREL G.M. 1960. Producing virus-free Cymbidiums. Am. Orchid Soc. Bull. 29: 495-497.

MURASHIGE T., SKOOG F. 1962. A revised medium for rapid growth and bioassays with tobacco tissue cultures. Physiol. Plant 15: 473-497.

RAMSAY M.M., STEWART J. 1998. Re-establishment of the lady's slipper orchid (Cypripedium calceolus L.) in Britain. Bot. J Linnean Soc. 126: 173-181.

SHEELAVANTMATH S.S., MURTHY H.N., PYATI A.N., ASHOK KUMAR H.G., RAVISHANKAR B.V. 2000. In vitro propagation of the endangered orchid, Geodorum densiflorum (Lam.) Schltr. through rhizome section culture. Plant Cell Tiss. Org. Cult. 60 (2): 151-154.

SZLACHETKO D. 1995. Zagrożenia gatunków z rodziny Orchidaceae na Pomorzu Zachodnim In: Żukowski W., Jackowiak B. (eds) Ginące i zagrożone rośliny naczyniowe Pomorza Zachodniego i Wielkopolski. Wydawnictwo Naukowe Bogucki. Poznań. (in Polish)

The International Plant Names Index (http://www.ipni.org)

VACIN E.F., WENT F.W. 1949. Some pH changes in nutrient solutions. Bot. Gaz. 110: 605-613.

VAJRABHAYA M. 1978. Tissue culture of dormant buds from Cattleya back bulbs. Orchid Rev. 86: 256-257.

Van WAES J.M., DEBERGH P.C. 1988. In vitro germination of some Western European orchids. Physiol. Plant. 67: 253-261

WERKMEISTER P. 1970. Light induction of geotropism and the control of proliferation and growth of Cymbidium in tissue culture. Bot. Gaz. 132: 346-350.

YAM T.W., ERNST R., ARDITTI J., NAIR H., WEATHERHEAD M.A. 1990. Charcoal in orchid seed germination and tissue culture media: a review. Lindleyana 5: 256-265. 